\title{
Research Article \\ Effects of Land Fragmentation on Productivity in Northwestern Ethiopia
}

\author{
Gashaw Tenna Alemu, ${ }^{1}$ Zewdu Berhanie Ayele, ${ }^{2}$ and Assefa Abelieneh Berhanu ${ }^{1}$ \\ ${ }^{1}$ Department of Rural Development and Agricultural Extension, Bahir Dar University, Bahir Dar, Ethiopia \\ ${ }^{2}$ Department of Agricultural Economics, Bahir Dar University, Bahir Dar, Ethiopia \\ Correspondence should be addressed to Gashaw Tenna Alemu; gtenna@yahoo.com
}

Received 16 March 2017; Revised 19 July 2017; Accepted 2 August 2017; Published 17 September 2017

Academic Editor: Albino Maggio

Copyright (c) 2017 Gashaw Tenna Alemu et al. This is an open access article distributed under the Creative Commons Attribution License, which permits unrestricted use, distribution, and reproduction in any medium, provided the original work is properly cited.

Generally, land fragmentation is a universal trait of all agricultural systems which affects farmland productivity and no one had documented a rural society where there was no land fragmentation. Hence, this study sought to ascertain the effects of land fragmentation on farmland productivity in the highland districts of Northwestern Ethiopia by using cross-sectional data collected from 240 respondents during 2015/16 production seasons and analyzed by using linear and Cobb-Douglass production functions. In land productivity model, $38 \%$ of variations in farmland productivity are explained by variations in independent variables including land fragmentation parameters. Average farmland size of 1.25 ha was obtained as minimum size that can generate minimum food and cash requirement of an average family of five adult equivalents. Hence, the government should come up with land use policy and population growth controlling program, which enables determining minimum economic farmland size, improving land productivity, and finding ways to strengthen off-farm activities and livestock sector to absorb more labor and enhance means of generating more income so as to decrease minimum farmland size required.

\section{Introduction}

Agriculture has always been an important sector in Ethiopia which is serving $85 \%$ of the population either directly or indirectly that placed the smallholder farmers as central focus of development policies and strategies. However, it had been characterized by a very low growth rate, estimated at about $1.4 \%$ per annum in real term, which was less than the growth rate of population, that is, $2.49 \%$ per annum, during the last three decades [1].

The rational use of agricultural land is influenced by land use limitations. One of the obstacles for agricultural development is land fragmentation [2-4]. Land fragmentation is defined as the situation in which a single farm or ownership consists of numerous spatially separated plots [5]. Likewise, according to Bizimana et al. [6] land fragmentation refers to farmers operating two or more geographically separated tracts of land, taking account of the distances between those parcels. Dominant problem associated with land fragmentation is the small size, irregular shape, and dispersion of parcels $[7,8]$. With this statement, in Ethiopia, about $92.26 \%$ of rural households operate on holdings of mean 1.4 ha which constitutes $72 \%$ of total crop area. The number of households operating on holdings smaller than or equal to $1 \mathrm{ha}$ (mean $0.73 \mathrm{ha}$ ) constitutes $72.1 \%$ of the total while the national average holdings estimate is about 0.8 ha [9]. This indicates that agricultural land fragmentation is a widespread phenomenon in highland areas of the country. The major causes are being land distribution and redistribution, inheritance rules, and risky peasant agriculture. In line with this Rahameto [10] stated that land fragmentation was widespread in North as well as South under all tenure systems and in many parts of Ethiopia.

Different research results [11-15] indicated that land fragmentation is often considered as the source of inefficiencies in crop productivity which is associated with production costs due to inefficient resource allocation; suboptimal usage of factor inputs that lowers overall returns to land due to losses on extra travel time, wasted space along borders, inadequate monitoring, and the inability to use certain 
types of machinery; hindering agricultural modernization and making it costly to modify adverse effects by consolidation schemes; and so forth. Empirically, they estimated that land fragmentation constitutes $60 \%$ of the total cash cost of production. However, fragmented land with different biophysical conditions allows farmers to reduce risks such as drought, flood, and fire, diversify crop mixtures, and ease seasonal labor bottlenecks [16]. Land fragmentation also allows farmers to grow a wide range of crops with different ripening time so that they may concentrate their labor at different plots at different time, thereby avoiding the period of labor intension and household labor bottlenecks [17].

In Northwestern highlands of Ethiopia, the demand for land has been increasing significantly in the last three decades. Available evidence shows that, over the years, the total land holding per household is becoming smaller and smaller. Given the rapidly growing population versus consequent land size fragmentation and degradation of natural resources, the opportunity to increase smallholders' farmland productivity through area expansion is limited [18, 19]. According to Enyew et al. [20], proportion of cultivated land in potentially productive highlands is $50-70 \%$ of the total land and the remaining land is mostly water logged or steep slope. This threat is credible as about $90 \%$ of the population of the Amhara National Regional State (ANRS) lives in the highland part of the region and $90 \%$ of the regularly cropped land is found there.

There are not many studies conducted related to land fragmentation in the country in general and ANRS in particular at different levels. Most of the studies [10, 2023] focused on the land tenure, land certification, and other related issues, which ignores the land fragmentation issues even if it is critical for productivity. In light of this, the study area, that is, the highland districts of West Gojjam Province, is characterized by small farm holding divided into small strips scattered over distant areas. Hence, land fragmentation appears to be the most acute problem of smallholder farmers in the highland areas where majority of the people reside. Therefore, it is self-justifying to give priority for investigating effects of land fragmentation on farming in the highland areas. Moreover, the advantages and disadvantages of land fragmentation depend entirely upon the local economic and natural environment. Each community should be considered as a unique case before a government decides to undergo any change against land fragmentation. Hence, this study was initiated to produce empirical information which serves as a basic source specifically about the districts and provide additional knowledge concerning land fragmentation and its effects to smallholder farmers' land productivity and farm income. The main hypothesis of this research was that "there is a significant variability of output or farm income under different conditions of land fragmentation parameters" in the study area.

\section{Literature Review}

Farm or parcel size is usually considered the physical size of land held in operation. It has been proved that a regression equation leads to biased estimates and mistakenly leads to an inference that there had been diseconomies of scale in land use, when conventional definition of size of a farm is used as measure of form size [24]. The landholding or parcel size and its influence on land fragmentation and/or agricultural productivity are an overall problem around the world. For example, in Nigeria and China, the impact of land fragmentation and landholding size has been investigated to rice farming. Ben-Chendo et al. [25] found out that landholding size of the rice farmers is relatively small and it can discourage the practice of rice framing. Therefore, the option would be enhancement of landholding size. Tan et al. [16] study showed that farmers with more and smaller plots tend to use fewer modern technologies and reduction of the average distance to plots and an increase in farm size decreased the total production costs per ton.

Relationship between farm size and productivity in developing countries is one of theoldest issues in the academic arena for analyzing the agrarian structure. The debate on farm size and productivity relationship intensified, when Sen [26] observed inverse relationship between farm size and output per hectare in Indian agriculture, suggesting that small farms are more productive compared to large ones. This relationship is explained by the relative advantage of using more family labor by small farms that may reduce the monitoring and supervision costs of hired labor. These findings show that equity does matter for efficiency in the agricultural sector and raise the question of redistributive land reform in most agrarian countries. Likewise, Feder [27] shows that small farmers have high labor/land ratios and could achieve higher yield per hectare. Moreover, different researchers in India found inverse relationship between farm size and productivity [28-34]. Additionally, Hossain [35], Berry and Cline [36], and Herdt and Mandac [37] found that the inverse relationship holds in the case ofIndonesia, the Philippines, and Bangladesh, respectively.

Despite a number of studies favoring the inverse relationship, there are different research results which did not find inverse rather positive relationship between farm size and productivity in India [38-48]. Moreover, Cornia [49] analyzed the relationship between factor inputs, yields, and labor productivity for farms of different sizes in 15 developing countries. These results showed a positive relationship between farm size and productivity in Bangladesh, Peru, and Thailand.

Increasing population entails fall in the landholding size and fragmentation into small parcels $[6,50]$. Parcel size is the primary characteristic to describe the land use conditions and to evaluate the land fragmentation. The simplest method is to calculate the average size of the landholding or parcel. Although this method is considered to be easy and comfortable, the main disadvantage is the fact that it does not describe the distribution of parcels by size [8]. When landholdings are fragmented into several small parcels which are spatially scattered and the distance from the farmhouse is varying, it hampers agricultural development in many ways [14, 51].

\section{Research Methodology}

West Gojjam, the study area, is one of the productive provinces in Northwestern Ethiopia. Based on the 2007 
census, this province has a total population of 2,106,596, of whom 1,058,272 are males and 1,048,324 females, with an area of $13,311.94 \mathrm{~km}^{2}$ and a population density of 158.25 . A total of 480,255 household heads (HHs) were counted in this province, which results in an average of 4.39 persons per household and 466,491 housing units [52].

Generally, for the purpose of this study, multistage random sampling procedures at five levels were employed for the selection of sample respondents. First, West Gojjam Province was purposively selected due to its high production potential with high population pressure and its highest severity of land fragmentation in Northwestern Ethiopia. Secondly, purposive sampling technique was used to come up with three districts, namely, Dega Damot, Quarit, and Sekela, which are relatively located in highland areas with fragmented landholding size. Thirdly, cluster random sampling technique was employed to categorize Peasant Kebele Administrations (PKAs) which are relatively located in highland and lowland areas. Fourthly, simple random sampling was employed to select 12 PKAs (4 PKAs from each district) which are located in highland areas. At last, by considering precision, homogeneity nature of samples, and simplicity of analysis, random sampling technique by using RANDBTWEEN formula in Microsoft Excel sheet was employed to select 240 samples $\mathrm{HHs}$ from the total HHs that the selected PKAs had. The principle of probability proportional to size or ratio sampling was used as a basis to fix the number of sample HHs selected from each PKA.

Data was collected from both primary sources, such as respondents through pretested individual interview schedule, key informant (KI) interviews, and focus group discussions (FGDs), and secondary sources, such as journal articles, books, extension package manuals, proclamations, reports, and others relevant to this study from the district agricultural offices, land administration and environmental protection offices, province departments, regional bureaus, and so on.

After completion of raw data collection, it was processed, entered, and analyzed by STATA version 12 computer aided statistical packages. The households' quantitative data was tabulated and analyzed by using both descriptive and inferential statistical tools such as percentage, mean, standard deviation, $t$-test, and chi-square test. The qualitative data were partly analyzed on spot during data collection to avoid forgetting and to be able to identify the covered through subsequent data collection by using interpretations, categorizations, and narrative explanation of facts.

Productivity of a farm is the ratio of the output it produces to the input it uses [53]. The study of productivity of resources requires the use of production function. Production function is defined as the basic concept in economic theory of production function based on experiments with crops and livestock and farm production based on cross-sectional and time series data [54]. Product or output is a function of or is dependent on the input of resource services [55]. Hence, the production function concept could be summarized as the set of all possible efficient relations between inputs and output given the current state of technological knowledge. In mathematical terms, the production function is assumed to be continuous and differentiable. After assessing previous studies [56-60] on similar topics and taking into account the laws of the production process, power function or Cobb-Douglass and linear production functions had been selected as appropriate functional forms. However, Gavian and Fafchamps [61] employed multiple linear regression model for the analysis of effects of land fragmentation on productivity. For the purpose of this study, linear production and Cobb-Douglass function were employed in the analysis of the effects of land fragmentation on productivity and to determine minimum farm size, respectively.

Most production function research had been based on single equation approach because of its computational simplicity. The implicit form of the single equation model that was used in this study was given as

$$
Y=f\left(\frac{x_{i}}{x_{i}}+1, x_{i}+2, \ldots, x_{i}+n, E\right) .
$$

The model indicated that $Y$, the net farm income or land productivity of all crops produced, and $x_{s}$ are factors of production and land fragmentation parameters including land, labor, and capital parameters. According to Singh [57] land is the most important factor of production, while labor is the second in importance and capital inputs seemed to play relatively lesser role in crop production. The perpendicular bar was used to indicate that all factors to the left of the bar are fixed in quantity. This symbolic representation of the production function does not explain the amount by which $Y$ changes. To express quantitative relationships between variables, the production function must be expressed in functional form and it was discussed separately in the result and discussion part.

\section{Result and Discussions}

4.1. Household Characteristics. Households are important institutional units for most development process including agricultural extension services delivery. Thus, discussing the demographic features and economic conditions of respondents would have a vital role in seeing the extents of variations of land productivity model as a result of land fragmentation parameters vis-a-vis socioeconomic variables. According to the survey result, the mean age of the total sample respondents was 47.11 years with minimum and maximum age of 33 and 74 years, respectively. The result of independent sample $t$-test indicated that there is a statistically significant mean difference (at $\leq 5 \%$ probability level) among respondents. The average family size of the respondent was found to be 5.91 with a standard deviation of 1.25 . However, independent sample $t$-test indicated no significant mean differences among them at $10 \%$ probability level. The educational level of sample respondents showed that $55.6 \%$ are illiterate, while $44.4 \%$ are literate. This result showed a significant mean difference $\left(x^{2}=77.242\right)$ between male headed households (MHHs) and female headed households (FHHs) at less than $1 \%$ significance level.

Land is the primary source of livelihood for all rural households. The size of the land reflects ownership of an important farm asset. The larger farm size implies more 
TABLE 1: Summary of linear regression result.

\begin{tabular}{|c|c|c|}
\hline Variables & Coefficient & $t$-ratio \\
\hline \multicolumn{3}{|l|}{ Dependent variable: land productivity } \\
\hline Average distance of parcels from homestead (minutes) & $-11.40^{* * *}$ & -2.51 \\
\hline Cultivated parcel number & $-13.98^{* * *}$ & -2.39 \\
\hline Average area of cultivated parcels owned $(\mathrm{Ha})$ & -125.84 & 1.52 \\
\hline Labor intensity (man-days/ha) & -0.23 & -0.45 \\
\hline Oxen power intensity (oxen days/ha) & $28.42^{* * *}$ & 3.19 \\
\hline Age of $\mathrm{HH}$ (years) & $-6.20^{*}$ & -1.67 \\
\hline Operational capital intensity (ETB/ha) & $2.87^{* * *}$ & 3.13 \\
\hline Constant & $1151.03^{* * *}$ & 4.91 \\
\hline$R^{2}$ & & 0.42 \\
\hline Adjusted $R^{2}$ & & 0.38 \\
\hline$F$-ratio & & $5.56^{* * *}$ \\
\hline Observation & & 240 \\
\hline
\end{tabular}

Source: our own computation (2016). ${ }^{*, *, * * *}$ Significant at less than $10 \%, 5 \%$, and $1 \%$ probability level, respectively.

resources and greater capacity to invest in farm and increased production. The processes through which land was obtained and the size of the land differed from household to household [18]. Nevertheless, almost all households had access to land even if the size of land acquired by most respondents was small. The mean land holding size of the respondents was 1.183 ha with a standard deviation of 1.025 , and there is a statistically significant mean difference $(t=-12.132)$ at less than $1 \%$ level of significance. With regard to livestock ownership, the survey result clearly showed that on average a $\mathrm{HH}$ had $3.75 \mathrm{TLU}$ with a standard deviation of 2.44. There was a significant mean deference $(t=-5.630)$ at less than $1 \%$ level of significance. Generally, it is obvious that livestock are important source of cash income in rural areas, which are used for purchasing different types of packages to increase production and productivity.

4.2. Determinants of Land Productivity. The effect of land fragmentation was analyzed by identifying factors influencing land productivity using linear production function. This was done based on the relationship established between land productivity (dependent variable) and the independent variables. Before running the model to estimate the equation of land productivity, the association between explanatory variables was checked using variance inflation factor (VIF), which shows how variance of estimate is inflated because of the presence of Multicollinearity [62]. In all cases, there is no serious problem of Multicollinearity since all values of VIF were below five and assumed minimum because value of VIF less than 10 does not bring serious problem of Multicollinearity [62].

The ordinary least square (OLS) method applied to the survey data provided the regression results summarized in Table 1 . The F-statistic ratio was highly significant at less than $1 \%$ probability level. This showed that the main (alternate) hypothesis formulated, that is, "there is a significant variability of output or farm income under different land fragmentation parameters," was accepted. The result showed that there is a considerable variation in output, which is not explained by the production function. As shown by value of adjusted coefficient of multiple determinations, only $38 \%$ of variation in land productivity is explained by variations in the independent variables included in the model. The possible reason for low explanatory power of the model might be due to the inability of capturing important natural factors. However, the estimated regression model can serve the objective, which was the effect of land fragmentation on land productivity.

\subsubsection{Land Fragmentation Parameters}

(1) Average Distance of Parcels from Homestead (Minutes). Agricultural land fragmentation parameter, average distance of parcels from homestead, is an average distance of cultivated parcels from homestead, which was measured, in walking time (minutes). It indicated average distance of parcels from homestead to cultivate land by a farm family. This research finding proved that land productivity was negatively affected by this variable at less than 0.01 significant level. Accordingly, it was reviewed [63-67] that distance wastes labor time by traveling between homesteads and parcels, becomes hindrance in transporting inputs from homestead to parcels, makes supervision and protection of the land difficult, entails long distances, loss of working hours, problem of transporting agricultural implements, and products, and results in small and uneconomic size of operational holdings. As a result, King and Burton [68] and Gavian and Fafchamps [61] concluded that the long distances between parcels reduce the level of crop productivity or income by inducing production costs.

(2) Cultivated Parcel Number. The number of cultivated parcels owned, another land fragmentation parameter, significantly ( $<1 \%$ probability level) but negatively affected land productivity. This implied that it would be optimal for the farmers to have the land holdings in fewer plots. Similar results had been found by Bizimana et al. [6] and Jha et al. 
[67], where there is a negative relationship between number of plots cultivated and the yields of crops and net farm income per hectare.

However, based on this research result, average size of parcels and labor intensity were found not significant in influencing farmland productivity. This result, insignificant relationship between average size of parcels and productivity, clearly shows the traditional nature of agricultural practices in the study area. This is because Deolalikar [46] and Dyer [69] stated that this type of relation may hold true in a relatively backward agriculture but it breaks down with the advancements in technology. Similarly, the weak relationship between labor intensity and productivity might be because of the presence of abundant labor power and working time, where time spent in walking from homestead, protecting parcels from wild life and bird attack, and close supervision does not reduce working time of farm activities. Similarly, Commander [70] found that there is no consistent association between average farm land size and productivity. However, Singh [57] and Gavian and Fafchamps [61] found that labor per hectare and farm size were significant and affected yield, the former positively and the latter negatively. Moreover, Maqbool et al. [71] found the regressing value of output per unit of cultivated area against the log of operational holding confirmed a negative relationship between farm size and productivity.

To sum up the issue, land fragmentation parameters, the overall finding of this research indicated that land fragmentation has a negative effect on yields and leads to small and uneconomic size of operational holdings. However, the efficiency of very small-scale farms can be enhanced by land consolidation programs. According to Bizimana et al. [6] land consolidation program allows reallocating relatively larger holdings to farmers in order to reduce the present dispersed distribution of land, so as to increase land productivity via allocating land to more proficient farmers. Therefore, enabling proficient farmers to access relatively larger land holdings can be attained through institutions and policies promoting efficiency in human resources and an efficient land (rental) market.

4.2.2. Socioeconomic Variables. Besides land fragmentation, different socioeconomic variables including but not limited to factors of production (labor and capital) would have an effect on land productivity. In line with this premises, oxen power intensity, operating capital intensity, labor intensity, and age were regressed in land productivity model.

(1) Oxen Power Intensity (Oxen Days/ha). The variation in oxen power intensity, which refers to the total oxen power used in crop production during the study year (2015/16) divided by total cultivated land area, significantly influenced land productivity at less than $1 \%$ probability level. An increment of oxen power by oxen day per hectare was associated with an increment of 28.42 ETB per hectare.

(2) Operational Capital Intensity (ETB/ha). Operating capital intensity, which is the amount of variable cost (the sum of values of seed, fertilizer, herbicide, and cost of hired laborer) used in crop production divided by total cultivated land area, significantly influenced land productivity at less than $1 \%$ probability level. An increment of operating capital by one ETB per hectare is associated with an increment of $2.87 \mathrm{ETB}$ per hectare.

(3) Age of HH (Years). In addition, age of household heads significantly influenced land productivity at less than $10 \%$ probability level. An increment of an age of household head by one year is associated with declining of land productivity by $6.20 \mathrm{ETB}$.

However, labor power intensity was not found to significantly influence land productivity. The probable reason is the availability of abundant labor power in the study area.

4.3. Net Farm Income Model Result. In this section, net farm income equation was estimated to determine minimum farm size. Hence, log transformed Cobb-Douglas production function was employed in estimating net farm income equation. Before running the model, the association between explanatory variables was checked by using VIF and in all cases there is no serious problem of Multicollinearity since all values of VIF were below five. According to the OLS regression result depicted in Table 2, the model was highly fitted to the data as shown by $F$-statistic, which was highly significant at less than $1 \%$ probability level. The coefficient of multiple determinations for the model was also significant at less than $1 \%$ probability level. Thus, it can be stated that with $99 \%$ confidence more than $68 \%$ of the variation in net farm income among the farmers is explained by the factors included in the model. Hence, the selected model fits to the available data. The regression result showed that four out of five independent variables included in the model significantly influence net farm income. These are area of cultivated land, oxen power used, operating capital, and age of household head.

Based on the result in Table 2, it is vivid that cultivated land area was one of the major limited resources upon which the farmers in the study area depend for their living. Variations in area of cultivated land (cropped land) were found to significantly influence variations in net farm income (at probability of $\leq 1 \%$ ). The elasticity estimate of net farm income was 0.41 with respect to cultivated land area, indicating that, other things being the same, a $1 \%$ increase in the area of cultivated land was associated with a $0.41 \%$ increase in net farm income. Similarly, oxen power input significantly influences net farm income (at $\leq 1 \%$ probability level). The elasticity estimate of this variable showed that a $1 \%$ increase in oxen power input (oxen days) led to about $0.42 \%$ increase in net farm income, while all other factors held constant. In addition, operating capital, the other limiting factor of crop production in the study area, significantly related to net farm income (at $\leq 5 \%$ probability level). The elasticity estimate of this variable showed that a $1 \%$ increase in operating capital was associated with about $0.15 \%$ increase in net farm income, while all other factors held constant. Lastly, the variation in age of household heads was found to be significant (at $\leq 10 \%$ 
TABLE 2: Log transformed Cobb-Douglas production function regression result.

\begin{tabular}{lcc}
\hline Variables & Coefficient & $t$-ratio \\
\hline Dependent variable: net farm income & & $6.69^{* * *}$ \\
\hline Constant & $0.41^{* * *}$ & 3.24 \\
Area of cultivated land (Ha) & $0.42^{* * *}$ & 3.32 \\
Total oxen power intensity (oxen days) & $0.15^{* *}$ & 2.04 \\
Operational capital (ETB) & $-0.30^{*}$ & -1.73 \\
Age of HHs (years) & -0.08 & -0.76 \\
Labor power (man-days) & & 0.7 \\
\hline$R^{2}$ & & 0.68 \\
\hline Adjusted $R^{2}$ & & $43.14^{* * *}$ \\
\hline -ratio & & 240 \\
\hline Observation & & \\
\hline
\end{tabular}

Source: our own computation (2016). ${ }^{*, * * * * * *}$ Significant at $10 \%, 5 \%$, and $1 \%$ probability level, respectively.

probability level) but negative in explaining variation in net farm income of the sample households. The elasticity estimate of the regression result showed that a $1 \%$ increase in age of household head was associated with about $0.3 \%$ decrease in net farm income, while all other factors held constant. This showed that, as age increases, there is a tendency towards increasing leisure time by the sample households' heads.

The overall result found that land fragmentation has a negative effect on farm profitability. This is probably due to inherent inefficiencies arising from the dispersion of land parcels. In line with this finding, Di Falco et al. [72] reported that land fragmentation has a detrimental effect on farm profitability. Moreover, Berhanu [59] established the relationships between net farm income from crop farming and cultivated land area, available family labor force, oxen power, direct cost (crop production and animal), irrigated land area and total land productivity, income from livestock, and share of coffee and chat income in gross farm income on Hararghe highlands, Ethiopia. He found land productivity, cultivated land area, and direct cost to be significant variables in the regression. He, finally, concluded that cultivated land is the limiting factor of the production.

The above estimated net farm income model was used to determine minimum farm size so as to examine the extent of subdivision of farms into smaller farms in the study area and how the livelihood of the people is affected due to diminution of farmland. In deciding the minimum requirement for an average farm family, Banerjee and Siroh [56] took an average expenditure incurred on different items. In this study, in determination of minimum farm size, an attempt had been made to estimate an area of cultivated land that generates subsistence requirements (1604 ETB) per average farm family of 5 adult equivalents as estimated in the model. The amount of money mentioned was equated with right hand side of the estimated net farm income equation. Then the equation was solved for cultivated land by keeping other variables constant at their average values (average for the sample households). The reason of using average value is that it is assumed to determine minimum farm size that can generate subsistence requirement for an average farm family. The average oxen power used (oxen days), age of household head, average labor input used, and average operating capital were 21.37 oxen days, 47.11 years, 97.81 man equivalents, 227 ETB, respectively. The estimated net farm income equation to be solved to determine minimum farm size is as follows:

$$
\begin{aligned}
\ln y_{i}= & 6.69+0.41 \ln x_{1}+0.42 \ln x_{2}-0.30 \ln x_{3} \\
& -0.07 \ln x_{4}+0.15 \ln x_{5},
\end{aligned}
$$

where $x_{1}$ is area of cultivated land (ha), $x_{2}$ is oxen power used (oxen days), $x_{3}$ is age of $\mathrm{HH}$ (years), $x_{4}$ is labor power used (man-days), and $x_{5}$ is operating capital (ETB).

By solving (2), farmland size of 1.25 ha was obtained as minimum size that can generate minimum food and cash requirement of an average farm family of five adult equivalents. This figure was less than the national average minimum farm size 1.53 ha per household having five members [63] which is estimated minimum requirement based on assumed expenditure on consumable and nonconsumable and minimum energy requirement. However, the figure is greater than minimum farm size of 1.18 ha needed to fulfill minimum food and cash requirement for an average of five adult family members per household which equated on the survey result conducted in Hararghe highlands [59]. The probable reasons for this variation are that the minimum farm size determined was under the existing technology, productivity, and prices of inputs and farm produce, which resulted in variations by increasing inputs and practices that can improve the productivity of land considerably. Based on this result, out of the total sample households, 33\% owned farmland size (cultivated and fallow land) less than the minimum farm size (1.25 ha). Therefore, one can infer that land owned by the households failed to support the farmers and their family at estimated assumed minimum food and cash requirement with the current land productivity.

The overall effects of agricultural land fragmentation on productivity and net farm income undermine the livelihood prospects of smallholder farmers in the study area. In light of this, Abdollahzadeh et al. [73] summarized as increasing production cost, preventing of performing timely operations such as water control, transplanting, and pest control, restricting the applications of modern technology 
(mechanization, irrigation), wasting of farmers' time by imposing unnecessary travel among land plots, crop production and yield decline, problem of monitoring farming activities, complicating of pest control and integrated farm management, and so on the major challenges associated with land fragmentation on smallholder farmers' livelihood.

\section{Conclusion and Policy Options}

(i) The result showed that there is a significance mean differences on productive resources ownership among smallholder farmers.

(a) Therefore, intervention strategies focused on improving accessibility of resources, that is, through provision of communal land, are crucial to minimizing income disparities between smallholder farmers who lease out their land and who plough by themselves.

(b) Moreover, improving the productivity of livestock sector could have an immense impact to improve the household income so that food security status at household level would be above threshold level.

(ii) Decrease of farmland size due to subdivision has resulted in farmland holding which does not support average farm household for about $33 \%$ of the sample households. Therefore, to overcome the problem of diminution, the government and policy makers have to come up with

(a) land use policy, which enables determining minimum economic farm size with higher productivity.

(iii) Determination of minimum farm size is dynamic process, which depends on family size, land productivity, oxen power used, income from off-farm activities and livestock sector, and so on. In this particular study area, efforts have to be made in

(a) improving land productivity,

(b) increasing utilization of oxen power,

(c) increasing utilization of operating cost,

(d) finding ways to strengthen off-farm activities and livestock sector to absorb more labor and enhance means of generating more income so as to decrease minimum farm size required.

(iv) The insignificant coefficient of labor showed the existence of plenty labor force with cheap wage rate. This is due to the highest population pressure on the highland areas of Northwestern Ethiopia. Simultaneously, this current population growth may further lead to further farmland diminution. Hence,

(a) population growth controlling programs through appropriate family planning services should be introduced in advance; (b) attempting to absorb the existing abundant or excess labor force in other sectors through facilitating different nonfarm activities as sources of employment and income by GOs and NGOs should be promoted.

(v) Last but not least, policy makers should not overlook the advantages of land fragmentation from the farmers' perspective and they should focus on whether consolidation programs lead to significant productivity that makes farmers better off or not, before issuance of policy on consolidation. The effects of agricultural land fragmentation parameters (distance of parcels, number of parcels owned, and average size of parcels) have to be considered separately so as to take proper measure on each of them.

\section{Conflicts of Interest}

The authors declare that there are no conflicts of interest regarding the publication of this paper.

\section{Acknowledgments}

The authors would like to acknowledge the College of Agriculture and Environmental Sciences of Bahir Dar University for funding this research and thank all academic and supporting staff for their continued and unreserved material, technical, and moral support during sampling and data collection process.

\section{References}

[1] M. Fekadu, "Analysis of technical efficiency of wheat production: a study in machakel district, Ethiopia. A thesis submitted to the school of graduate studies of alemaya university," Tech. Rep., Haramaya, Ethiopia, 2004.

[2] J. Hristov, "Assessment of the impact of high fragmented land upon the productivity and profitability of the farms," in The Case of the Macedonian Vegetable Growers, p. 23, 2016, http://stud.epsilon.slu.se/472/1/Hristov_J_010909.

[3] O. C. Austin, A. C. Ulunma, and J. Sulaiman, "Exploring the link between land fragmentation and agricultural productivity," International Journal of Agriculture and Forestry, vol. 2, no. 1, pp. 30-34, 2012.

[4] I. Vijulie, E. Matei, G. Manea, O. Cocoş, and R. Cuculici, "Assessment of agricultural land fragmentation in Romania, a case study: Izvoarele commune, Olt County," Acta Geographica Slovenica, vol. 52, no. 2, pp. 403-430, 2012.

[5] J. W. Bentley, "Economic and ecological approaches to land fragmentation: in defense of a much-maligned phenomenon," Annual review of anthropology. Vol. 16, pp. 31-67, 1987.

[6] C. Bizimana, W. L. Nieuwoudt, and S. R. D. Ferrer, "Farm size, land fragmentation and economic efficiency in southern Rwanda," Agrekon, vol. 43, no. 2, pp. 244-262, 2004.

[7] X. P. Gonzalez, M. F. Marey, and C. J. Alvarez, "Evaluation of productive rural land patterns with joint regard to the size, shape and dispersion of plots," Agricultural Systems, vol. 92, no. 1-3, pp. 52-62, 2007. 
[8] D. Demetriou, J. Stillwell, and L. See, "A new methodology for measuring land fragmentation," Computers, Environment and Urban Systems, vol. 39, pp. 71-80, 2013.

[9] A. Haile Gabriel, Supply Response and Rural Differentiation: Development Strategies and the Ethiopian Peasantry, Institute of Social Studies, The Hague, The Netherlands, 2000.

[10] D. Rahameto, Land Tenure and Land Policy after the Derg, Working Paper 8, Institute of Development Research, and Addis Ababa University, 1994.

[11] M. F. Mcpherson, "Land fragmentation: adverse, beneficial and for whom?" in Efficiency Estimation from Cobb Douglass' Production Functions with Composed Error, W. Meeusen and V. den Broeck, Eds., vol. 18, International Economic Review, 1983.

[12] S. Simpson, "Land fragmentation in developing countries: the optional choice and policy implications," Explor. Econ. Hist, vol. $25,1987$.

[13] O. Shuhao, "Land fragmentation and rice production: a case study of small farmers in jiangxi province," D. O. Awotide and P. O. Agbola, Eds., China, 2005.

[14] V. V. Kakwagh, J. A. Aderonmu, and A. Ikwuba, "Land fragmentation and agricultural development in tivland of benue state, Nigeria," Current Research Journal of Social Sciences, vol. 3, no. 2, pp. 54-58, 2011.

[15] K. Deininger, D. Monchuk, N. K. Hari, and S. Sudhir, Does Land Fragmentation Increase the Cost of Cultivation? Evidence from India, Policy Research Working Paper 7085, World Bank Group, Development Research Group, Agriculture and Rural Development Team, November 2014.

[16] S. Tan, N. Heerink, G. Kruseman, and F. Qu, "Do fragmented landholdings have higher production costs? evidence from rice farmers in northeastern jiangxi province, China," China Economic Review, vol. 19, no. 3, pp. 347-358, 2008.

[17] S. A. Todorova and D. Lulcheva, "Economic and social effects of land fragmentation on Bulgarian agriculture," Journal ofCentral European Agriculture, vol. 6, no. 4, pp. 555-562, 2005.

[18] Six-month work plan execution and evaluation report, ANRS BoA (Amhara National Regional State Bureau of Agriculture, Bahir Dar, Ethiopia, 2016.

[19] Six-month work plan execution and evaluation report, ANRS BoLAU (Amhara National Regional State Bureau of Land Administration and Use), Bahir Dar, Ethiopia, 2016.

[20] A. Enyew, G. Yihenew, T. Abate, A. Solomon, and A. A. Abiye, "Impact of land certification on sustainable land resource management in the amhara region, Ethiopia," Tech. Rep., Dry lands Coordination Group, Miljøhuset G9, Norway, Ethiopia, April 2014, DCG Report No. 75.

[21] C. Tesfaye, "The effect of land administration system on sustainable land resource conservation in amhara region, Ethiopia," the Case of Dessie Zuria and Tehulederie Districts, 2007.

[22] G. Berhanu, W. Gebremedhin, D. Yigzaw, G. Tilahun, and T. Worku, "Sustainable land management through market oriented commodity development: case studies from Ethiopia," in Proceedings of the Conference on International Research on Food Security, Natural Resource Management and Rural Development, University of Hamburg, 2009, Tropentag.

[23] T. Shimelles, Z. Islam, and T. Parviainen, "Effects of Land Tenure and Property Rights on Agricultural Productivity in Ethiopia, Namibia and Bangladesh," in Discussion Papers No 33, University of Helsinki Department of Economics and Management, Helsinki, Finland, 2009.
[24] R. K. Sampath, "Farm size and land use intensity in Indian agriculture," Oxford Economic Papers, vol. 44, no. 3, pp. 494501, 1992.

[25] G. N. Ben-Chendo, O. C. Korie, U. A. Essien, and I. J. Uhuegbulem, "Determinants of land holding size among rice farmers in southeast, Nigeria," Asian Review of Environmental and Earth Sciences, vol. 1, no. 3, pp. 56-60, 2014.

[26] A. K. Sen, "An aspect of indian agriculture," Economic Weekly, vol. 14, pp. 243-246, 1962.

[27] G. Feder, "The relation between farm size and farm productivity. The role of family labor, supervision and credit constraints," Journal of Development Economics, vol. 18, no. 2-3, pp. 297-313, 1985.

[28] D. Mazumdar, "Size of farm and productivity: a problem of indian peasant agriculture," Economica, vol. 32, pp. 161-173, 1965.

[29] C. H. H. Rao, "Alternative explanations of the inverse relationship between farm size and output per acre in India," The Indian Economic Review, vol. 1, pp. 1-12, 1966.

[30] G. R. Saini, "Holding size, productivity and some related aspects of indian agriculture," Economic and Political Weekly, vol. 26, pp. A79-A85, 1971.

[31] K. Bharadwaj, "Notes on farm size and productivity," Economic and Political Weekly, vol. 9, no. 13, pp. A11-A24, 1974.

[32] A. N. Chaddha, "Farm size and productivity revisited: some notes fromrecent experience of punjab," Economic and Political Weekly, vol. 13, no. 39, pp. A82-A96, 1978.

[33] A. K. Ghose, "Farm Size and Land Productivity in Indian Agriculture: A Reappraisal," The Journal of Development Studies, vol. 16, no. 1, pp. 27-49, 1979.

[34] S. Bhalla, "Farm size productivity and technical change in indian agriculture," in Agrarian Structure and Productivity in Developing Countries, R. A. Berry and W. R. Cline, Eds., pp. 141193, John Hopkins Press, Baltimore, Maryland, 1979.

[35] M. Hossain, "Farm Size, tenancy and land productivity: an analysis of farmlevel data in bangladesh agriculture," Bangladesh Development Studies, vol. 5, pp. 285-348, 1977.

[36] R. A. Berry and R. W. Cline, Agrarian Structure and Productivity in Developing Countries, John Hopkins Press, Baltimore, Maryland, 1979.

[37] R. W. Herdt and M. A. Mandac, Modern Technology and EconomicEfficiency of Philippines Rice Farmers, vol. 29, Economic Development and Cultural Change, 1981.

[38] A. P. Rao, "Size of Holdings and Productivity," Economic and Political Weekly, pp. 989-991, 1967.

[39] N. Bhattacharya, G. R, and Saini., "Farm size and productivity: a fresh look," Economic and Political Weekly, vol. 7, no. 26, pp. A63-A72, 1972.

[40] W. Khan and N. R. Tripathy, Intensive Agriculture and Modern Inputs: Prospects of Small Farmers-A Study in West Godavari District, Hyderabad:National Institute of Community Development, 1972.

[41] C. H. H. Rao, Technological Change and the Distribution of Gains in IndianAgriculture, Macmillan, Delhi, 1975.

[42] M. Chattopadhyay and A. Rudra, Size-Productivity Revisited, vol. 11, Economic and Political Weekly, 39, 1976.

[43] B. Dasgupta, Agrarian Change and the New Technology in India, Geneva:United Nations Research Institute, 1977.

[44] G. R. Saini, "Farm size productivity and some related issues in indias agriculture: a review," Agricultural Situation in India, vol. 34:11, pp. 777-783, 1980. 
[45] F. S. Bagi, "Relationship between farm size and economic efficiency: an analysis of farm-level data from haryana (India)," Canadian Journal of Agricultural Economics, vol. 29, no. 3, pp. 317-326, 1981.

[46] A. B. Deolalikar, "The inverse relationship between productivity and farm size: a test using regional data from India," American Journal of Agricultural Economics, vol. 63, no. 2, pp. 275-279, 1981.

[47] V. Rao and T. Chotigeat, "The inverse relationship between size of land holdings and agricultural productivity ( India).," American Journal of Agricultural Economics, vol. 63, no. 3, pp. 571-574, 1981.

[48] P. Roy, "Transition in agriculture: empirical indicators and results (evidence from punjab, India)," The Journal of Peasant Studies, vol. 8, no. 2, pp. 212-241, 1981.

[49] G. A. Cornia, "Farm size, land yields and the agricultural production function: An analysis for fifteen developing countries," World Development, vol. 13, no. 4, pp. 513-534, 1985.

[50] S. T. Akkaya Aslan, K. S. Gundogdu, and I. Arici, "Some metric indices for the assessment of land consolidation projects," Pakistan Journal of Biological Sciences, vol. 10, no. 9, pp. 13901397, 2007.

[51] G. S. Niroula and G. B. Thapa, "Impacts and causes of land fragmentation, and lessons learned from land consolidation in South Asia," Land Use Policy, vol. 22, no. 4, pp. 358-372, 2005.

[52] The 2007 Population and Housing Census of Ethiopia: Central Statistics Authority, CSA (Central Statistics Authority), Addis Ababa, Ethiopia, 2007.

[53] T. Coelli, D. S. Rao, and G. E. Battese, An Introduction to Efficiency and Productivity Analysis, Kluwer Academic Publishers, Boston, Dordrecht, London, 1998.

[54] E. O. Heady and J. L. Dillon, Agricultural Production Functions: U.S.A. Iowa State University, 1961.

[55] E. O. Heady, "Economics of Agricultural Production and Resource Use: Prentice-Hall Inc. Englewood Cliffs, 1952".

[56] B. N. Banerjee and A. S. Siroh, "Identification of small farmers in chanduli teshil, district varanai," Indian Journal of Agricultural Economics, pp. 185-191, 1975.

[57] J. P. Singh, "Resource use, farm size, and returns to scale in a backward agriculture in eastern uttar pradesh," Indian Journal of Agricultural Economics, vol. 30, pp. 31-46, 1975.

[58] M. Upton, Farm Management in Africa: The Principles of Production and Planning, Oxford University Press, 1979.

[59] A. Berhanu, Analysis of Land Size Variation and its Effects: The Case of Smallholder Farmers in the Hararghe Highlands. [MSc Thesis], Alemaya University, Alemaya, Ethiopia, 1992.

[60] T. B. Tshibaka, "Labor in the Rural Household Economy of the Zairian Basin: Research Report 90," International Food Policy Research Institute. Zaire, vol. 90, 1992.

[61] S. Gavian and M. Fafchamps, "Land tenure and allocative efficiency in Niger," American Journal of Agricultural Economics, vol. 78, no. 2, pp. 460-471, 1996.

[62] D. N. Gujarati, Basic Econometrics, McGraw Hill Inc, New York, NY, USA, 3rd edition, 1995.

[63] Study Report on Land Distribution and Redistribution, MoA (Ministry of Agriculture), Addis Ababa, Ethiopia, 1989.

[64] Ethiopia Development Options, P. Siegfried, F. Cheru, S. Brune, and E. Chole, Eds., Development/Agriculture/Africa, Zed Books Ltd, London, UK, 1990.
[65] Y. Gebeyehu, "Population pressure, agricultural land fragmentation and land use: A case study of Dale and Shashemene Woredas, Southern Ethiopia," in Proceedings of the fourth Annual Conference on the Ethiopian, Addis Ababa, Ethiopia, 1995.

[66] O. Getachew, "Land Tenure Arrangements, Potentials and Problems in the LUPO Intervention Zones: Finfinnee, Ethiopia, $2000 "$.

[67] R. Jha, H. K. Nagarajan, and S. Prasanna, Land Fragmentation and its Implications for Productivity: Evidence from Southern India. ASARC Working Paper, ASARC Working Paper, Australia, 2005.

[68] R. King and S. Burton, "Land fragmentation: notes on a fundamental rural spatial problem," Progress in Human Geography, vol. 6, no. 4, pp. 475-494, 1982.

[69] G. Dyer, "Farm size - farm productivity re-examined: Evidence from rural egypt," The Journal of Peasant Studies, vol. 19, no. 1, pp. 59-92, 1991.

[70] S. Commander, The Sate and Agricultural Development in Egypt Since, Overseas Development Institute, London, 1987.

[71] H. S. Maqbool, Shahid I., and A. D. Sheikh, "Farm Size Productivity" Relationship; Recent Evidence from Central Punjab, vol. 50, Pakistan Economic and Social Review, Lahore, Pakistan, 2nd edition, 2012.

[72] S. Di Falco, I. Penov, A. Aleksiev, and T. M. van Rensburg, "Agrobiodiversity, farm profits and land fragmentation: evidence from bulgaria," Land Use Policy, vol. 27, no. 3, pp. 763-771, 2010.

[73] G. Abdollahzadeh, K. Kalantari, A. Sharifzadeh, and A. Sehat, "Farmland fragmentation and consolidation issues in Iran; an investigation from landholder's viewpoint," Journal of Agricultural Science and Technology, vol. 14, pp. 1441-1452, 2012. 


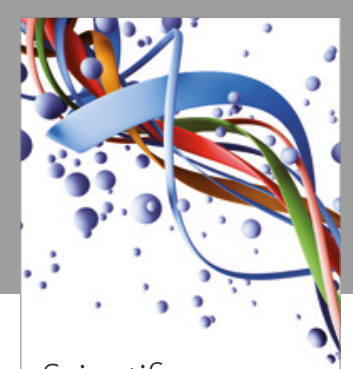

Scientifica
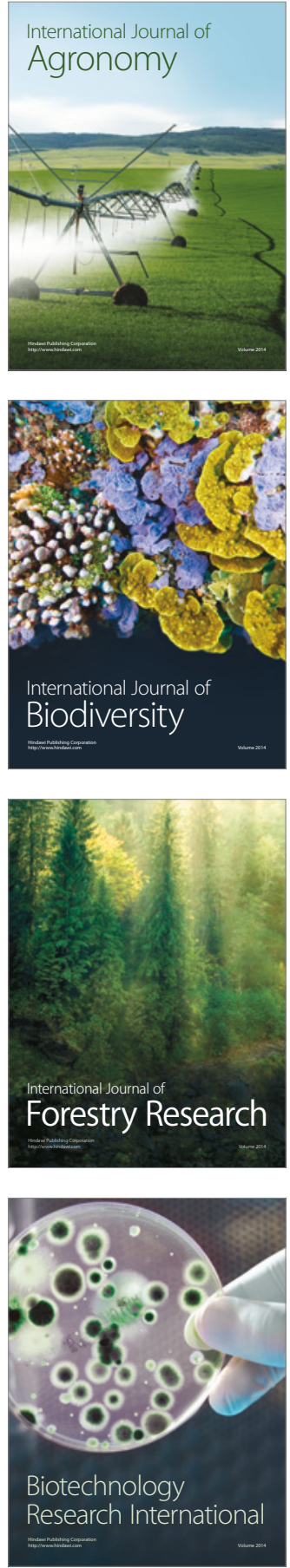
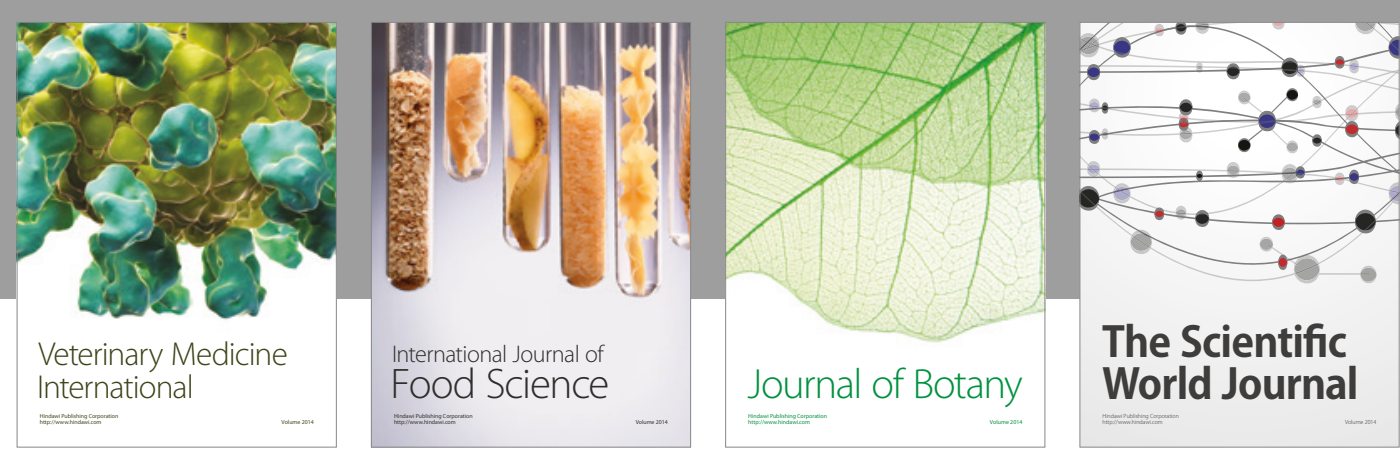

The Scientific

\section{World Journal}

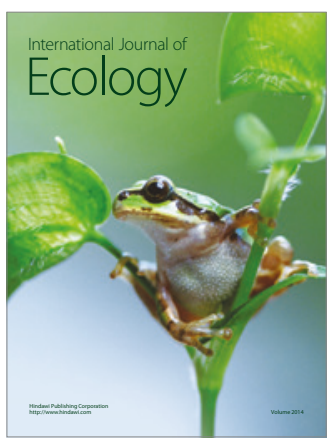

\section{Hindawi}

Submit your manuscripts at

https://www.hindawi.com
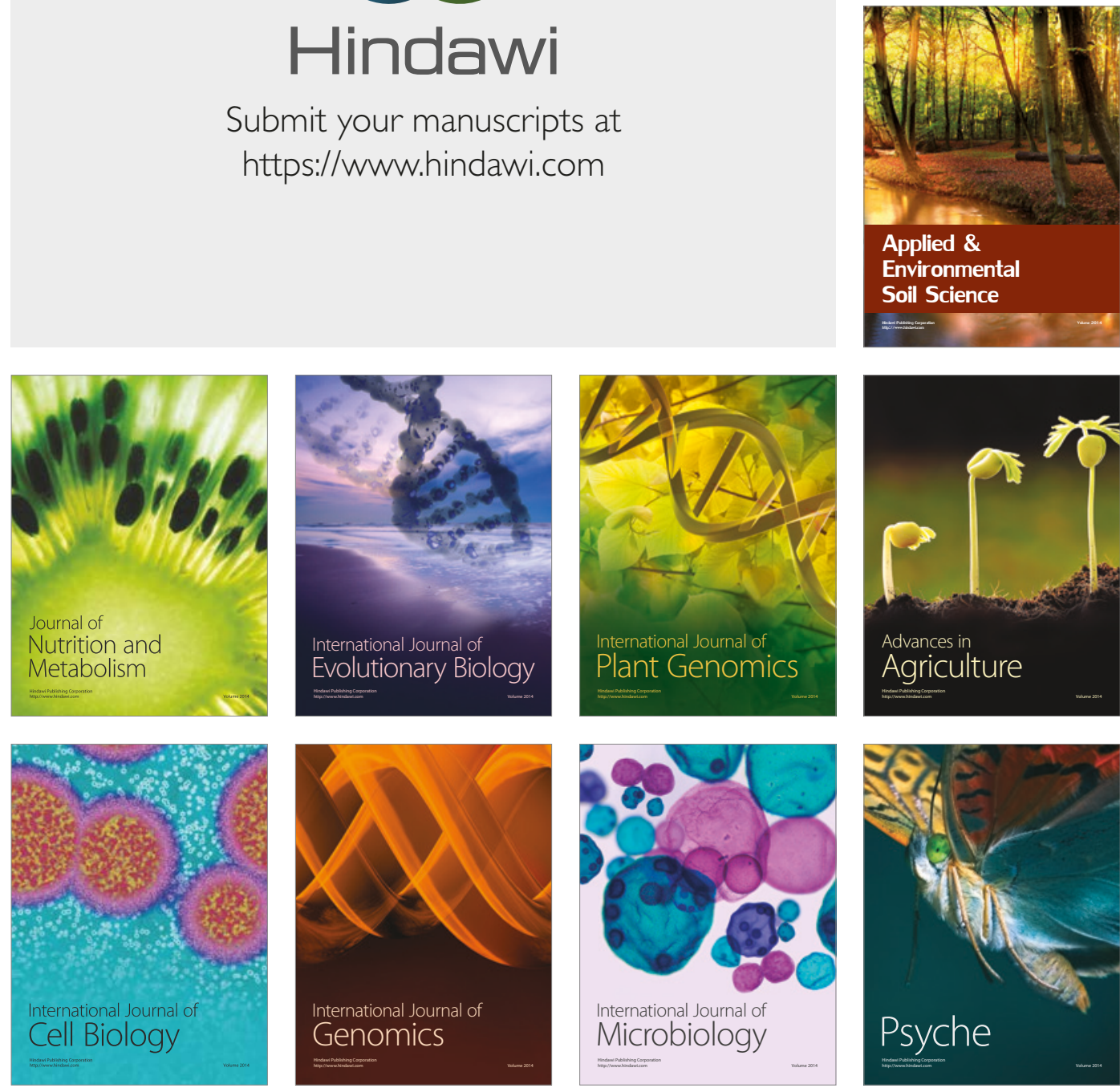

hternational Journal of Microbiology
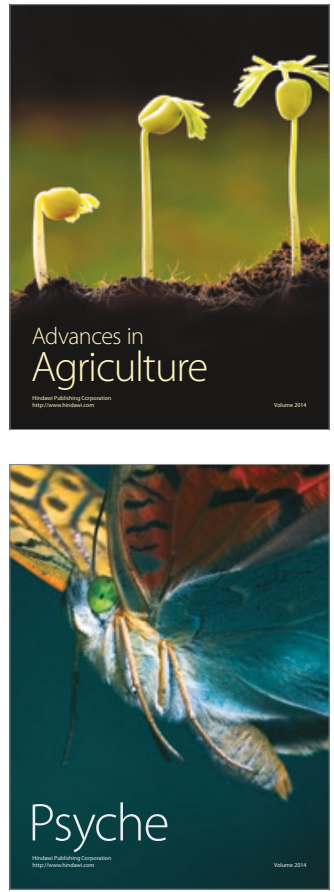